\title{
Analisis Perputaran Persediaan Barang Dalam Meningkatkan Laba Pada Kopkar Gotong Royong PT. PLN (Persero) Area Palopo
}

\author{
Muh. Najib Kasim ${ }^{1}$ \\ Riska $^{2}$ \\ No. HP $0811427544^{1}$ \\ ${ }^{1}$ Alamat Korespondensi: \\ Email:
}

\begin{abstract}
Abstrak
Perputaran persediaan adalah suatu ukuran yang menunjukkan berapa kali persediaan berputar dalam satu periode. Perputaran persediaan terhadap laba perusahaan harus memperhatikan persentase laba karena semakin besar laba maka perputaran persediaan terhadap laba meningkat.

Tujuan dari penelitian ini adalah untuk mengetahui dan menganalisis perputaran persediaan barang dalam meningkatkan laba pada Kopkar Gotong Royong PT. PLN (Persero) Area Palopo

Hasil penelitian ini menunjukkan bahwa harga pokok penjualan pada tiap tahunnya mengalami kenaikan. Ini menunjukkan bahwa semakin besar angka perputaran persediaan maka semakin bagus karena berarti perusahaan efisien dalam penyediaan persediaannya.

Apalagi tingkat perputaran persediaan rendah artinya tingkat penjualannya juga rendah, sehingga pendapatan mengalami penurunan dan hal tersebut akan menimbulkan penurunan laba operasi yang diperoleh karena biaya-biaya tambahan yang harus dikeluarkan oleh perusahaan seperti biaya pemeliharaan dan biaya penyimpanan persediaan barang dagang.
\end{abstract}

\section{Kata kunci : Perputaran persediaan dan Laba}

\section{Pendahuluan}

Koperasi merupakan salah satu bentuk usaha yang sesuai dengan demokrasi Indonesia. Azas yang digunakan dalam pengelolaan koperasi mencerminkan pelaksanaan dari demokrasi ekonomi yaitu azas kekeluargaan. Pengelolaan koperasi tidak hanya mengandalkan kualitas pengurus saja akan tetapi juga mengharapkan partisipasi para anggotanya.
Dengan memperhatikan azas yang terkandung didalam koperasi maka ada nilai lebih dari koperasi yang tidak dimiliki oleh badan usaha lainnya. Nilai-nilai kesetiakawanan, kekeluargaan, gotong royong, solidaritas, demokrasi dan kebersamaan merupakan suatu nilai lebih tersendiri bagi koperasi. Koperasi diharapkan akan mampu menumbuhkan dan mengembangkan ekonomi rakyat dan mewujudkan kehidupan ekonomi yang demokratis. Dalam kehidupan ekonomi yang semakin mengglobal koperasi seharusnya mempunyai ruang gerak dan kesempatan usaha yang luas yang menyangkut kepentingan kehidupan ekonomi rakyat.

Didalam Undang-Undang RI No 25 Tahun 1992 tentang Perkoperasian, dinyatakan bahwa koperasi bertujuan memajukan kesejahteraan anggota pada khususnya dan masyarakat pada umumnya serta ikut membangun tatanan perekonomian nasional dalam rangka mewujudkan masyarakat yang maju, adil, dan makmur berlandaskan Pancasila dan Undang-Undang Dasar 1945.

Dengan demikian dapat disimpulkan bahwa koperasi mempunyai dua dimensi yaitu dimensi ekonomi dan dimensi sosial. Dimensi 
ekonomi yaitu koperasi didalam menyelenggarakan usahanya bertujuan untuk mensejahterakan anggota. Sedangkan dimensi sosial yaitu koperasi merupakan kumpulan orangorang yang bekerjasama atas azas kekeluargaan.

Koperasi adalah suatu Badan Usaha, maka kecuali bertujuan memenuhi kebutuhan anggotanya juga harus mampu menghasilkan keuntungan atau laba. Kemampuan suatu perusahaan menghasilkan laba dalam periode tertentu disebut Rentabilitas. SHU atau laba yang besar bukanlah jaminan bahwa koperasi tersebut telah bekerja dengan efisien. Efisiensi baru dapat diketahui dengan membandingkan laba yang diperoleh itu dengan kekayaan atau modal yang menghasilkan laba tersebut. Efisiensi sangat diperlukan oleh koperasi karena akan memungkinkan koperasi dapat beroperasi seekonomis mungkin.

Kopkar Gotong Royong adalah koperasi yang keanggotaannya bersifat terbuka dan umum untuk semua golongan yang ada di lingkup kerja PT. PLN Area Palopo, apakah itu Pegawai, tenaga kontrak, cleaning service, Pencatat meter dan yang terkait dengan PLN. Tanpa membedakan suku, agama, dan ras. Kopkar Gotong Royong merupakan salah satu jenis koperasi yang membutuhkan modal yang cukup untuk menggerakkan dan meningkatkan seluruh bidang usahanya. Modal kerja mempunyai hubungan yang erat dengan kegiatan operasi sehari-hari, karena selalu dibutuhkan untuk membelanjakan koperasi secara terus menerus.

Munawir (2002:77), perputaran persediaan merupakan ratio antara jumlah harga pokok barang yang dijual dengan nilai rata-rata persediaan yang dimiliki oleh perusahaan. Tingkat perputaran persediaan mengukur perusahaan dalam memutarkan barang dagangan dan menunjukkan hubungan antara barang yang diperlukan untuk menunjang atau mengimbangi tingkat penjualan yang ditentukan.

Dalam melaksanakan kegiatan pemasaran tidak terlepas akan kebutuhan barang-barang dagangan yang menjadi faktor utama dalam menunjang jalannya aktivitas pemasaran. Dengan terpenuhinya akan barang tepat pada waktunya, maka kegiatan suatu perusahaan akan dapat berjalan dengan lancar sesuai dengan tujuan yang akan dicapaitersebut. Tanpa adanya persediaan barang dagangan, koperasi akan menghadapi resiko dimana pada suatu waktu tidak dapat memenuhi keinginan dari pada pelanggannya. Tentu saja ini akan berakibat buruk tehadap koperasi, karena secara tidak langsung koperasi menjadi kehilangan kesempatan untuk memperoleh keuntungan (laba) yang seharusnya didapatkan atau diperoleh.

Manajemen persediaan merupakan fungsi manajerial yang sangat penting, karena pemeriksaan fisik atas persediaan ini banyak melibatkan investasi rupiah atau investasi financial dan mempengaruhi efektifitas dan efisiensi kegiatan perusahaan, sebagaimana halnya di koperasi.

Perputaran persediaan terhadap laba perusahaan harus memperhatikan persentase laba karena semakin besar laba maka perputaran persediaan terhadap laba meningkat. Perputaran persediaan adalah suatu ukuran yang menunjukkan berapa kali persediaan berputar dalam satu periode. Apabila tingkat perputaran persediaan 
tinggi maka tingkat penjualannya akan tinggi, sehingga pendapatan dapat meningkat serta laba operasi juga akan meningkat. Apabila tingkat perputaran persediaan rendah artinya tingkat penjualannnya juga rendah, sehingga pendapatan mengalami penurunan dan hal tersebut akan menimbulkan penurunan laba operasi yang diperoleh karena biaya-biaya tambahan yang harus dikeluarakan oleh perusahaan seperti biaya pemeliharaan dan biaya penyimpanan persediaan barang dagang.

\section{Metode Penelitian}

Penelitian dilakukan pada Kopkar Gotong Royong, yang beralamatkan di Jalan Andi Kambo No.70 Kota Palopo. Jenis dan sumber data yang digunakan yaitu Data primer merupakan data yang diperoleh dari Kopkar Gotong Royong berupa laporan keuangan dan data sekunder merupakan data yang diperoleh peneliti melalui literaturliteratur yang telah ada, baik itu berupa buku, jurnal, skripsi, tesis serta disertasi yang dipublikasikan dan tidak dipublikasikan.

Metode pengumpulan data yang digunakan yaitu melalui wawancara Yaitu teknik pengumpulan data melalui proses tanya jawab dalam penelitian yang berlangsung secara lisan antara dua orang atau lebih bertatap muka mendengarkan secara langsung informasiinformasi atau keterangan-keterangan lisan melalui dialog langsung antara peneliti dengan para informan. Observasi Yaitu pengamatan langsung terhadap objek kajian yang sedang berlangsung untuk memperoleh keterangan dan informasi sebagai data yang akurat tentang hal-hal yang diteliti serta untuk mengetahui relevansi antara jawaban informan dengan kenyataan yang ada, dengan melakukan pengamatan langsung yang ada di lapangan yang erat kaitannya dengan objek penelitian. Studi pustaka merupakan langkah yang penting sekali dalam metode ilmiah untuk mencari sumber data sekunder yang akan mendukung penelitian. Cara yang dilakukan dengan mencari data-data pendukung (data sekunder) pada berbagai literatur baik berupa buku-buku, dokumen-dokumen, makalah-makalah hasil penelitian serta bahan-bahan referensi lainnya yang berkaitan dengan penelitian. Serta Dokumentasi dapat diasumsikan sebagai sumber data tertulis yang terbagi dalam dua ketegori yaitu sumber resmi dan sumber tidak resmi. Sumber resmi merupakan dokumen yang dibuat/dikeluarkan oleh lembaga/perorangan atas nama lembaga. Sumber tidak resmi adalah dokumen yang dibuat/dikeluarkan oleh individu tidak atas nama lembaga. Dokumen yang akan dijadikan sebagai sumber referensi dapat berupa hasil rapat, laporan pertanggung jawaban, surat, dan catatan harian.

\section{Metode Analisis Data}

Bertitik tolak dari masalah dan hipotesis yang telah dikemukakan sebelumnya, maka dalam membahas dan menganalisis permasalahan sekaligus membuktikan hipotesis maka penulis menggunakan metode analisis kuantitatif yaitu dengan mengadakan eksplorasi lebih lanjut serta menemukan fakta dan menguji teori-teori yang timbul. Dalam penelitian ini tentunya analisis dilakukan dengan mengeksplorasi teori-teori yang berkaitan dengan perputaran persediaan dan penentuan laba pada Kopkar Gotong Royong. data 
yang diperlukan adalah laporan keuangan tahun $2011-2013$.

Dalam hal ini, Bambang Riyanto (2008:34) memberikan formulasi metode dasar dasar pembelanjaan perusahaan yang dapat digunakan adalah sebagai berikut :

1. Harga Pokok Penjualan

Menghitung harga pokok penjualan adalah dengan cara menambahkan persediaanbarang dagang awal dengan pembelian bersih dikurang persediaan akhir, maka perhitungannya adalah sebagai berikut:

HPP = Pers. Awal + Pembelian bersih Pers.akhir

2. Perputaran Persediaan

Analisis Pengaruh Perputaran Persediaan Barang Terhadap Laba pada Kopkar gotong royong. Suatu ukuran yang dapat digunakan untuk menilai pengelolaan persediaan barang dagangan dalam suatu koperasi adalah dengan melihat tingkat perputaran persediaannya. Perputaran persediaan adalah suatu ukuran yang menunjukkan berapa kali persediaan berputar dalam satu periode.harga pokok barang yang terjual dalam waktu satu tahun dibagi dengan rata-rata nilai persediaan barang dagang.

Harga Pokok Penjualan

a. Perputaran Persediaan $=$

Persediaan Rata - rata

Laba bersih setelah pajak

b. Persentase Laba Tahun $=$ $\mathrm{x} 100 \%$

Penjualan c. Perputaran persediaan terhadap laba selama 3 tahun tersebut adalah sebagai berikut:

Perputaran persediaan terhadap laba

$=$ Perputaran Persediaan $\mathrm{x}$ Persentase laba

\section{Hasil Analisis dan Pembahasan}

\section{Analisis Data}

Penulis akan membahas mengenai datadata yang telah diketahui, yang merupakan data dari hasil penelitian lapangan dengan menggunakan metode kuantitatif.

Dalam hal ini, Bambang Riyanto (2008:34) memberikan formulasi metode dasar dasar pembelanjaan perusahaan yang dapat digunakan adalah sebagai berikut :

1. Harga Pokok Penjualan

Menghitung harga pokok penjualan adalah dengan cara menambahkan persediaan barang dagang awal dengan pembelian bersih dikurang persediaan akhir, maka perhitungannya adalah sebagai berikut:

HPP2011 = Pers. Awal + Pembelian bersih - Pers.akhir

$=18.017 .565+306.747 .710-9.923 .243$

$=314.842 .032$

HPP2012 = Pers. Awal + Pembelian bersih - Pers.akhir $=9.923 .243+408.717 .669-19.706 .250$ $=398.934 .662$

HPP2013 = Pers. Awal + Pembelian bersih - Pers.akhir $=19.706 .250+477.846 .187-13.275 .328$ $=484.277 .109$

Dari perhitungan harga pokok penjualan pada Kopkar Gotong Royong jumlah Harga Pokok Penjualan pada tahun 2011 sebesar Rp. 
314.017.565,- pada tahun 2012 dan 2013 mengalami peningkatan sebesar Rp. 398.934.662,sampai Rp. 484.277.109,--.

2. Perputaran persediaan

$$
\text { Analisis Pengaruh Perputaran }
$$

Persediaan Barang Terhadap Laba pada Kopkar gotong royong. Suatu ukuran yang dapat digunakan untuk menilai pengelolaan persediaan barang dagangan dalam suatu koperasi adalah dengan melihat tingkat perputaran persediaannya. Perputaran persediaan adalah suatu ukuran yang menunjukkan berapa kali persediaan berputar dalam satu periode. Harga pokok barang yang terjual dalam waktu satu tahun dibagi dengan rata-rata nilai persediaan barang dagang.

a. Perputaran Persediaan = $\begin{aligned} \text { Persediaan Rata }- \text { rata }\end{aligned}$

Tabel 1

Perhitungan Perputaran Persediaan Kopkar Gotong Royong

\begin{tabular}{|c|c|c|c|}
\hline Keterangan & Tahun 2011 & Tahun 2012 & Tahun 2013 \\
\hline Harga Pokok Penjualan (Rupiah/Tahun) & 314.842 .032 & 398.934 .662 & 484.277 .109 \\
\hline 1. Persediaan Awal (Rupiah/Tahun) & 18.017 .565 & 9.923 .243 & 19.706 .250 \\
\hline 2. Persediaan Akhir (Rupiah/Tahun) & 9.923 .243 & 19.706 .250 & 13.275 .328 \\
\hline Jumlah 1 + & 27.940 .808 & 29.629 .503 & 32.981 .578 \\
\hline Persediaan Rata-rata (Rupiah/Tahun) & 13.970 .404 & 14.814 .751 & 16.490 .789 \\
\hline
\end{tabular}

Sumber Data : Kopkar Gotong Royong

Harga pokok penjualan pada tahun 2011 sampai 2013 mengalami kenaikan. Tahun2011 sebesar Rp. 314.842.032,- sampai Rp. 398.934.662,- pada tahun 2013 sebesar Rp.484.277.109,- persediaan awal untuk periode tahun 2011 sebesar Rp.18.017.565,- namun pada tahun 2012 mengalami penurunan sebesar Rp. 9.923.243,- dan mengalami kenaikan yang signifikan pada tahun 2013 sebesar Rp. 19.706.250,-. persediaan akhir untuk tahun 2011 sebesar Rp. 9.923.243,- menjadi Rp.19.706.250,namun pada tahun 2012 mengalami penurunan sebesar Rp. 13.275.328,- persediaan rata- rata untuk tahun 2011 sampai 2013 mengalami- kenaikan setiap tahunnya, pada tahun 2011 sebesar Rp 13.970.404,- pada tahun 2012 sebesar Rp.14.814.751,- dan pada tahun 2013 sebesar Rp 16.490.789,-

Berikut ini perhitungan Perputaran Persediaan dari tahun 2011 sampai 2013 sebagai berikut : 
Perputaran Persediaan Tahun 2011

Perputaran Persediaan Tahun 2011

Perputaran Persediaan Tahun 2011

Perputaran Persediaan Tahun 2012

Perputaran Persediaan Tahun 2012

Perputaran Persediaan Tahun 2012

Perputaran Persediaan Tahun 2013

Perputaran Persediaan Tahun 2013

Perputaran Persediaan Tahun 2013
HPP2011

$$
\begin{aligned}
& \text { Pers. Rata - rata } 2011 \\
& 314.842 .032 \\
& \text { = ----------- } \\
& =22,536 \\
& \text { Pers. Rata }- \text { rata } 2012 \\
& 398.934 .662 \\
& \text { = } 14.814 .751 \\
& =26,928
\end{aligned}
$$

Berdasarkan perhitungan diatas dapat diketahui bahwa perputaran persediaan pada setiap tahun mengalami peningkatan yaitu tahun 2011 adalah Rp. 22,536, pada tahun 2012 sebesar Rp. 26,928 dan pada tahun 2013 adalah Rp. 29,366 disebabkan harga pokok penjualan pada tiap tahunnya mengalami kenaikan. Ini menunjukkan bahwa. Semakin besar angka perputaran persediaan maka semakin bagus karena berarti perusahaan efisien dalam penyediaan persediaannya. Dari hasil penelitian dan analisis masalah yang ada maka pemecahan masalah dari Analisis Pengaruh Perputaran Persediaan Barang dalam menigkatkan Laba pada Kopkar Gotong Royong adalah sebagai berikut :. 
Tabel 2

Perincian HPP, Persediaan Dan Total Perputaran Persediaan

\begin{tabular}{|l|l|l|l|l|}
\hline \multicolumn{1}{|c|}{ Keterangan } & \multicolumn{1}{|c|}{ Tahun 2011 } & \multicolumn{1}{c|}{ Tahun 2012 } & \multicolumn{1}{c|}{ Tahun 2013 } & \multicolumn{1}{c|}{ Total } \\
\hline $\begin{array}{l}\text { Harga Pokok } \\
\text { Penjualan }\end{array}$ & 314.842 .032 & 398.934 .662 & 484.277 .109 & 1.198 .053 .803 \\
\hline Persediaan rata-rata & 13.970 .404 & 14.814 .751 & 16.490 .789 & 45.275 .944 \\
\hline Perputaran Persediaan & 22,536 & 26,928 & 29,366 & 78,83 \\
\hline $\begin{array}{l}\text { Selisih dari tahun ke } \\
\text { tahun Periode }\end{array}$ & 4,392 & 2,438 & & 6,83 \\
\hline $\begin{array}{l}\text { Selisih ke } \\
\text { Tahun Awal ke } \\
\text { Tahun Akhir }\end{array}$ & & & 6,83 \\
\hline
\end{tabular}

Sumber data : hasil olahan

Dari tabel diatas dapat diketahui bahwa pada tahun 2011 sampai tahun 2013 perputaran persediaan sebesar Rp. 78,83 dengan selisih tahun awal ke tahun akhir sebesar 6,83 yang artinya mengalami peningkatan perputaran persediaanya terjadi pada tahun 2011 ke tahun 2013, dikarenakan tahun 2011 ke tahun 2012 selisih
4,392 sedangkan tahun 2012 ketahun 2013 selisih 2,438 . Setelah menganalisis perputaran persediaan maka dapat ditentukan berapa persentase laba dalam tahun 2011 sampai 2013.

b. Perputaran Persediaan Terhadap Laba Untuk menghitung perputaran persediaan terhadap laba yaitu :

Persentase Laba Tahun 2011

$$
\begin{aligned}
& \text { Laba bersih setelah pajak } \\
& =\frac{\text { - }}{\text { Penjualan }} \\
& \text { 113.994.330 } \\
& =\quad 428.836 .362 \\
& =0,265 \times 100 \% \\
& =26,5 \%
\end{aligned}
$$


Persentase Laba Tahun 2012

$$
\begin{aligned}
& \text { Laba bersih setelah pajak } \\
& =\frac{\text { Penjualan }}{\text { P }} \\
& =\frac{122.769 .458}{528.056 .480} \\
& =0,232 \times 100 \% \\
& =23,2 \% \\
& \text { Laba bersih setelah pajak }
\end{aligned}
$$

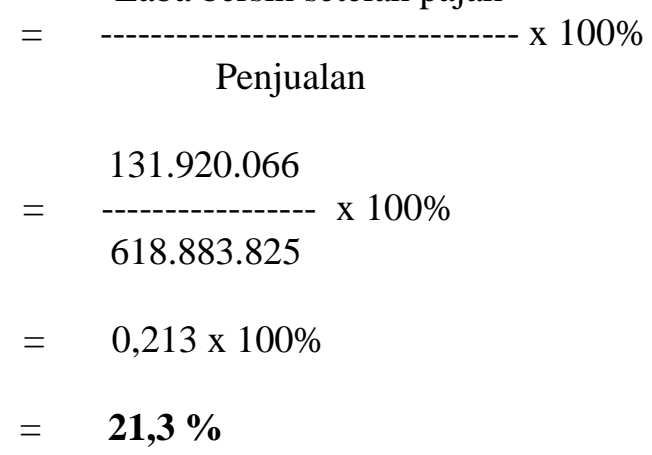$$
\text { Persentase Laba Tahun } 2013
$$

Berdasarkan analisis persentase laba yang telah diperhitungkan, persentase laba ini menunjukkan mengalami penurunan setiap tahunnya untuk tahun 2011 sebesar 26,5\% Sampai 23,2 \% untuk tahun 2012 dan mengalami penurunan lagi sebesar 21,3\% pada tahun 2013 kedalam perhitungan persentase laba dapat diketahui bahwa hasilnya, berikut ini perincian persentase laba yang akan dihitung kedalam perputaran persediaan terhadap laba.

C. Perputaran persediaan terhadap laba selama 3 tahun tersebut adalah sebagai berikut:

Perputaran persediaan terhadap laba 2011

$=$ Perputaran Persediaan Tahun $2011 \mathrm{X}$

Persentase laba

$=22,536 \times 26,5 \%$

$=\mathbf{5 , 9 7 2}$
Perputaran persediaan terhadap laba 2012

$=$ Perputaran Persediaan Tahun 2012 x Persentase laba

$=26,928 \times 23,2 \%$

$=6,247$

Perputaran persediaan terhadap laba 2013

= Perputaran Persediaan Tahun 2013 x Persentase laba

$=29,366 \times 21,3 \%$

$=6,254$ 
Tabel 3

Perputaran persediaan terhadap laba

\begin{tabular}{|l|l|l|l|l|}
\hline Tahun & Perputaran Persediaan & Persentase laba & Hasil & \multirow{2}{*}{ Total 3 Tahun } \\
\cline { 1 - 3 } 2011 & 22,536 & $26,5 \%$ & 5,972 & \multirow{2}{*}{18,473} \\
\hline 2012 & 26,928 & $23,2 \%$ & 6,247 & \\
\hline 2013 & 29,366 & $21,3 \%$ & 6,254 & \\
\hline
\end{tabular}

Sumber data : hasil olahan

Berdasarkan tabel 3 Perputaran persediaan terhadap persentase laba tahun 2011 adalah 5,972, pada tahun 2012 dengan besar Perputaran persediaan terhadap persentase laba adalah 6,247, dan pada tahun 2013 adalah sebesar 6,254 setiap tahun meningkat. Total perputaran persediaan terhadap persentase laba selama 3 tahun tersebut adalah 18,473 . Dengan perhitungan perputaran persediaan terhadap laba tersebut diketahui semakin besar perputaran persediaan maka perputaran persediaan terhadap laba semakin meningkat. Persentase laba semakin menurun setiap tahunnya karena adanya biaya operasional yang semakin meningkat.

\section{Kesimpulan}

Berdasarkan penelitian yang telah dilakukan di KOPKAR GOTONG ROYONG PT.PLN (Persero) Area Palopo untuk mengetahui perputaran persediaan barang dengan menggunakan Laba Rugi maka penelitian dapat menyimpulkan bahwa :

1. Tahun 2011 sampai tahun 2013 Kopkar Gotong Royong PT.PLN (Persero) Area Palopo. Untuk Perputaran Persediaannya pada tahun 2011 adalah Rp. 22,536, pada tahun 2012 sebesar Rp. 26,928 dan pada tahun 2013 adalah Rp.
29,366 disebabkan harga pokok penjualan pada tiap tahunnya mengalami kenaikan. Ini menunjukkan bahwa semakin besar angka perputaran persediaan maka semakin bagus karena berarti perusahaan efisien dalam penyediaan persediaannya.

2. Bila dilihat pada tahun 2011 sampai tahun 2013 untuk Perputaran Persediaan terhadap Laba pada Kopkar Gotong Royong PT.PLN (Persero) Perputaran persediaan terhadap persentase laba tahun 2011 adalah 5,972, pada tahun 2012 dengan besar Perputaran persediaan terhadap persentase laba adalah 6,247, dan pada tahun 2013 adalah sebesar 6,254 setiap tahun meningkat. Total perputaran persediaan terhadap persentase laba selama 3 tahun tersebut adalah 18,473. Dengan perhitungan perputaran persediaan terhadap laba tersebut diketahui, semakin besar perputaran persediaan maka perputaran persediaan terhadap laba semakin meningkat.

\section{Saran}

1. Sebaiknya pihak perusahaan agar lebih meningkatkan HPP agar perputaran persediaan barang yang dilakukan KOPKAR GOTONG ROYONG PT. PLN (Persero) Area Palopo 
semakin meningkat dan lebih baik. Karena semakin besar HPP maka semakin banyak pula laba yang diperoleh.

2. Sebaiknya pihak perusahaan agar meningkatkan Laba KOPKAR GOTONG ROYONG PT. PLN (Persero) Area Palopo. Karena semakin besar perputaran persediaan maka perputaran persediaan terhadap laba semakin meningkat.

\section{Daftar Pustaka}

Alexandri, Moh. $\quad$ Benny. 2009. ManajemenKeuangan Bisnis teori dan soal. Bandung : Penerbit Alfabeta.

Alwan Sri Kustono. 2009. Pengaruh Ukuran, devidend Payout, Risiko Spesifik dan Pertumbuhan Perusahaan terhadap Praktik Perataan Laba padaPerusahaan Manufaktur Studi Empiris Bursa Efek Jakarta 2002-2006,Jurnal Ekonomi BisnisNo 14, Nopember

Angkoso,Nandi. 2006. Akuntansi Lanjutan. Jakarta : PT. Rineka Cipta.

Bambang, Riyanto. 2000. Dasar-dasar Pembelanjaan Perusahaan, Edisi Keempat, Yogyakarta, BPFE.

2008. Dasar-dasar Pembelanjaan Perusahaan, Edisi Keenam, Yogyakarta, BPFE.

Benny Alexandri dan Lina Ismawati. 2005.Manajemen Keuangan Teori dan Praktikum,Bandung:UNIKOM.

Chariri dan Gozal. 2003. Teori Akuntansi, Badan Penerbit Universitas Diponegoro, Semarang.

Harahap, Sofyan Safri. 2001. Teori Akuntansi Laporan Keuangan.Bumi Aksara, Bandung.

2008. Analisis Kritis atas Laporan Keuangan. Edisi 1. Jakarta : PT. Graham ilmu.
Harnanto. 2002. Akuntansi Keuangan Menengah, BPFE, Yogyakarta

Yogyakarta
Younajemen Keuangan, BPFE,

Jumingan.2008. Analisis Laporan Keuangan. Jakarta: Bumi Aksara.

Juniarti. 2005. Analisis Laporan Keuangan. Jakarta : PT. Bumi Aksara

Kusnadi, Hendar, 2005. Ekonomi Koperasi (untuk Perguruan Tinggi) Edisi Ke-2,FE UI, Jakarta.

Lalu, Sumayang. 2003. Dasar-Dasar Manajemen Produksi dan Operasi. Salemba Empat : Jakarta

Munawir, S. 2002. Analisis Laporan Keuangan, Edisi Ke-4, BPFE, Jogyakarta.

Munawir,S. 2004. Analisa Laporan Keuangan. Yogyakarta : Liberty

Muslich.2003. Manajemen Keuangan Modern. Jakarta : Bumi Aksara.

Nani ,Syahriana. 2006. Analisis Faktor-Faktor yang Mempengaruhi Praktik Perataan Laba pada Perusahaan Manufaktur di BEJ (1999-2002), Skripsi, Fakultas Ekonomi Universitas Islam Indonesia, Yogyakarta

Ristono, Agus. 2009. Manajemen Persediaan Edisi 1. Jakarta : Graham Ilmu.

Sri Kustono. 2008. Dasar-dasar Organisasi dan Manajemen, Ghalia Indonesia.

Soemarso, SR. 2004. Akuntansi Suatu Pengantar Edisi ke-4, Rineka Cipta, Jakarta.

Stice, James D \& Earl K. Stice. 2011. Akuntansi Keuangan. Jakarta : Salemba Empat.

Sumbraman.2009. Manajemen Keuangan 1 Edisi ke-5,Literata Lintas Media, Jakarta.

Takarini, Nurjanti dan Erni Ekawati, 2003, "Analisis Rasio Keuangan 
Vol. 04 No. 02

dalamMemprediksi Perubahan Laba Pada Perusahaan Manufaktur di Pasar ModalIndonesia", Ventura, Vol. 6 No. 3.

Yuliati, Marwati. 2007. Dasar-dasar Akuntansi 2, Edisi ke-5, STIE YKPN,Yogyakarta.

Zaki, Baridwan. 2000. Intermediete Accounting, Edisi ke-7, BPFE, Jogyakarta. 